\title{
Differential Growth Responses of Apple Species to Chilling and Root Pruning
}

\author{
Michael A. Arnold and Eric Young ${ }^{2}$ \\ Department of Horticultural Science, North Carolina State University, Raleigh, NC 27695-7609 \\ Additional index words. chilling requirement, dormancy, root regeneration potential, root regeneration capacity, \\ budbreak, Malus domestics, Malus anis, Malus prunifolia, Malus $\mathbf{x}$ robusta, Malus antonovka, Malus borwinka, Malus \\ ranetka
}

\begin{abstract}
Malus dometica Borkh., M. anis, M. prunifolia Borkh., M. $\times$ robusta Rehd., M. antonovka, M. borwinkw, and $M$. ranetka bare-root seedlings were chilled at $5 \mathrm{C}$ for $0,400,800,1200$, or 1600 hours. After chilling treatments, one-half of the seedlings were root-pruned and all seedlings were placed in a greenhouse for 15 days. Quantitative differences between species in the timing and magnitude of new root and shoot growth responses to chilling were observed. Root pruning decreased and delayed the production of roots $<0.6 \mathrm{~mm}$ in diameter in response to chilling, while the production of larger roots was less affected. Regeneration of both root types differed among species. For new large ( $\geq 0.6 \mathrm{~mm}$ in diameter) root growth criteria, interactions between chilling hours and species were apparent. Chilling requirements and growing degree hour requirements for vegetative budbreak of each species were estimated.
\end{abstract}

Recent studies indicated an enhancement of root regeneration potential in $M$. domestica following exposure to chilling temperatures (Young and Werner, 1984b, 1985b, 1986). Similar enhancements of root growth following artificial chilling or exposure to winter conditions have been reported for other species (DeWald et al., 1985; Farmer, 1975; Lathrop and Mecklenburg, 1971; Stone and Norberg, 1979; Webb, 1976, 1977). For $M$. domestics (Young and Werner, 1985b) and Taxus cuspidata Sieb. and Zucc. (Lathrop and Mecklenburg, 1971), this enhancement is thought to be perceived by the root system. However, quantitative data on chilling enhancement of $M$. domestics root growth are lacking.

Differences among species in root regeneration capacity following exposure to various levels of chilling have been reported (Webb, 1977). Differences in root regeneration capacity in response to exposure to chilling temperatures have also been reported between commercial apple rootstock (Young and Werner, 1984b, 1985b) and between half-sib families of Pinus taeda L. (DeWald et al., 1985). Such differences in root and shoot growth responses to chilling might be useful in apple cultivar and rootstock breeding. While root pruning has often been shown to reduce subsequent new shoot growth (Arnold and Struve, 1989a, 1989b; Geisler and Ferree, 1984) and sometimes root regeneration capacity (Arnold and Struve, 1989b), we found no information on the interaction of root pruning and chilling on root growth or on the effect of root size on the chilling response.

The objectives of this experiment were to: 1) quantify the effect of chilling on root and shoot growth, 2) determine if differences in root regeneration potential exist between species of Malus, 3) determine if root pruning alters root and shoot growth responses to chilling, and 4) estimate the chilling requirements and growing degree hour requirements for vegetative budbreak of the species included in this study.

Received for publication 31 Mar. 1989. Paper no. 12122 of the Journal Series of the North Carolina Agricultural Research Service, Raleigh, NC 27695-7601. This study will be included as part of a dissertation to be written in partial fulfillment of the requirements for the $\mathrm{PhD}$ degree by M.A.A. The use of trade names in this publication does not imply endorsement by the NCARS of the products named, nor criticism of similar ones not mentioned. The cost of publishing this paper was defrayed in part by the payment of page charges. Under postal regulations, this paper therefore must be hereby marked advertisement solely to indicate this fact.

'Graduate Research Assistant.

${ }^{2}$ Professor.

\section{Materials and Methods}

One-year-old seedlings of $M$. domestics, M. anis, M. antonovka, M. prunifolia, M. x robusta, M. borwinka, and M. ranetka were lifted bare-root in early November from the nursery (Lawyer's Nursery, Plains, Mt.) after receiving <200 chilling hours. After lifting, seedlings were wrapped in polyethylene with roots surrounded by moist sphagnum peat, enclosed in waxed cardboard boxes, and shipped to Raleigh, N.C. There, they were placed in a cooler maintained at $13 \mathrm{C}$ until $15 \mathrm{Jan}$. 1988 , then placed in a 5C cooler. After O, 400, 800, 1200, and $1600 \mathrm{hr}$ of chilling, 10 uniform seedlings of each species were removed from the cooler. Average seedling fresh weight $(\mathrm{g})$, shoot length $(\mathrm{cm})$, and number of vegetative buds were 16,40 , 34 for $M$. domestics; 18, 45, 32 for M. anis; 24, 45, 26 for $M$. prunifolia; 25, 106, 46 for $M$. x robusta; 22, 40, 25 for $M$. antonovka; 17, 45, 33 for $M$. borwinka; and 22, 97, 45 for $M$. ranetka. All seedlings were single stem whips (i.e., not more than one terminal bud per seedling) and only vegetative buds were present. On five seedlings of each species, all lateral roots were removed and the taproot pruned to $20 \mathrm{~cm}$ (root-pruned seedlings). Fresh weights of the removed root tissues were recorded. The remaining five seedlings of each species were left intact (unpruned seedlings). Total fresh weights were measured directly. Root fresh weights were determined nondestructively by the method of Young and Werner (1984a). Shoot fresh weights were determined by subtraction. Seedlings were planted in waxed cardboard milk cartons (2.3 liters) containing Turface (Applied Industrial Materials Co., Deerfield, Ill.) medium and placed in the greenhouse in a completely randomized design. Weekly, $125 \mathrm{mg} \mathrm{N} /$ liter from $20 \mathrm{~N}-8.7 \mathrm{P}-16.6 \mathrm{~K}$ water-soluble fertilizer (Peters Fertilizer Products, Fogelsville, Pa.) was applied. Temperatures were set at 24/18C (day/night) for 9 and $15 \mathrm{hr}$, respectively. Natural photoperiods were used.

At 3-day intervals, the number of buds broken (green showing between bud scales) and number of new shoots elongating 3 $\mathrm{mm}$ or more were recorded. Seedlings were destructively harvested at day 15. Characteristics measured included new and old shoot lengths, new and old shoot fresh weights, new shoot dry weight, total number of buds, old root fresh weight, new root fresh and dry weights, number and length of roots $\geq 0.6$ $\mathrm{mm}$ in diameter (large roots), and number of roots $<0.6 \mathrm{~mm}$ in diameter (small roots). Diameters of a random sample of large roots per plant were measured under a dissecting microscope. New root : new shoot ratios, percent budbreak (number of buds 
Table 1. Least squares means significance levels for hours of chilling at SC (C), species (S), root pruning (P), and interactions for various growth characteristics of apple seedlings.

\begin{tabular}{|c|c|c|c|c|c|c|c|c|c|c|c|c|}
\hline Treatment & $\begin{array}{c}\text { Root } \\
\text { surface } \\
\text { area }\end{array}$ & $\begin{array}{l}\text { New root } \\
\text { fresh wt }\end{array}$ & $\begin{array}{c}\text { New } \\
\text { root } \\
\text { dry wt }\end{array}$ & $\begin{array}{c}\text { Large } \\
\text { root } \\
\text { length }\end{array}$ & $\begin{array}{l}\text { No. } \\
\text { small } \\
\text { roots }\end{array}$ & $\begin{array}{l}\text { No. } \\
\text { large } \\
\text { roots }\end{array}$ & $\begin{array}{c}\text { Root } \\
\text { to } \\
\text { shoot } \\
\text { dry wt }\end{array}$ & $\begin{array}{c}\text { Percent } \\
\text { budbreak }\end{array}$ & $\begin{array}{l}\text { Percent } \\
\text { shoots } \\
>3 \mathrm{~mm}\end{array}$ & $\begin{array}{c}\text { New } \\
\text { shoot } \\
\text { length }\end{array}$ & $\begin{array}{c}\text { New } \\
\text { shoot } \\
\text { fresh wt }\end{array}$ & $\begin{array}{c}\text { New } \\
\text { shoot } \\
\text { dry wt }\end{array}$ \\
\hline 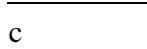 & NS & NS & & NS & $* * *$ & NS & $\mathrm{NS}$ & $* * *$ & $* * *$ & $* * *$ & $* * *$ & $\$^{* *}$ \\
\hline s & & & ** & & $* * *$ & $* * *$ & & $* * *$ & $* * *$ & $* *$ & $* * *$ & $\$ * *$ \\
\hline $\mathrm{P}$ & NS & NS & NS & NS & $* * *$ & NS & NS & NS & NS & $* * *$ & $* * *$ & $* * *$ \\
\hline $\mathrm{CxS}$ & & & NS & & NS & NS & NS & NS & NS & NS & $\mathrm{NS}$ & $\mathrm{NS}$ \\
\hline $\mathrm{C} \times \mathrm{P}$ & NS & NS & $\mathrm{NS}$ & NS & $\begin{array}{l}* * * \\
* * *\end{array}$ & $\underset{* *}{N S}$ & NS & NS & NS & & $* * *$ & $* * *$ \\
\hline $\mathrm{S} \times \mathrm{P}$ & & & & & & & NS & NS & NS & NS & *** & $* * *$ \\
\hline CXSXP & NS & NS & NS & NS & NS & NS & $\mathrm{NS}$ & NS & NS & NS & NS & NS \\
\hline
\end{tabular}

$* * * *^{*} * *{ }^{, N s}$ Significant at $P \leq 1 \%, 0.1 \%, 0.01 \%$, or not significant, respectively.
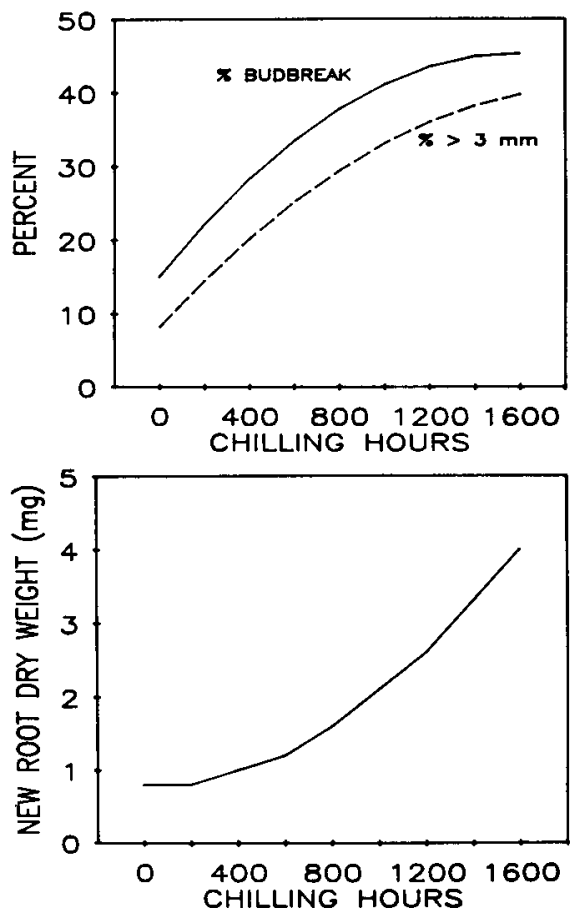

Fig. 1. Main effects of chilling hours at 5C (across species and rootpruning treatments) on budbreak, percent buds elongating $\geq 3 \mathrm{~mm}$, and new root dry weight of seedlings after15 days in a greenhouse. Regression equations are presented in Table 2.

broken/totaI number of buds), large root surface area (3. $\left.\left.\left.14 *\left\{{\text { radius } *\left[\text { square root of }\left(\text { radius }^{2}+\text { new root length }\right.\right.}^{2}\right)\right]\right\}\right)$, and growing degree hours (GDH) (\{[(day temperature - $4.5 \mathrm{C}$ )*hours at day temperature + (night temperature - $4.5 \mathrm{C}$ )*hours at night temperature ${ }^{*}$ days) required to reach $90 \%$ of maximum observed budbreak were calculated. After factorial analysis (7 species x 5 chilling levels x 2 root pruning levels) appropriate interactions and main effects were analyzed using least-squares means procedure and polynomial regression (SAS Institute, 1985).

\section{Results and Discussion}

Shoot growth responses. No 3-way interactions were significant at the $1 \%$ level (Table 1), allowing the interpretation of main effects and 2-way interactions not involved in significant higher level interactions. Across species and root-pruning treatments, final percent budbreak (after 15 days in the greenhouse) began to decrease in rate after $=1200$ chilling hours $(\mathrm{CH})$ (Fig. 1 , Table 2). The number of buds elongating $\geq 3 \mathrm{~mm}$ after 15 days in the greenhouse followed a similar pattern, but did not plateau until near $1600 \mathrm{CH}$ (Fig. 1). Across chilling and rootpruning treatments, species differences in final percent budbreak were evident. A larger percentage of buds broke in $M$. prunifolia, $M$. × robusta, $M$. ranetka, and $M$. antonovka than in $M$. domestics, M. anis, and M. borwinka (Table 3).

Regardless of chilling treatment, root pruning tended to reduce new shoot growth as measured by length, fresh weight, and dry weight (Table 4). The effect was significant in $M$. prunifolia, $M$. × robusta, $M$. antonovka, and M. ranetka (Table 4). Across species, the tendency for root pruning to reduce shoot growth was evident regardless of chilling treatment (Fig. 2, Table 2). As $\mathrm{CH}$ increased, the effect became more pronounced (Fig. 2). The rate of increase in new shoot fresh and dry weights with increasing $\mathrm{CH}$ was less for root-pruned plants than unpruned plants through $1600 \mathrm{CH}$. Also, the rate of new shoot growth of root-pruned plants began to decrease between 1200 and $1600 \mathrm{CH}$, whereas the rate of new shoot growth in unpruned plants was not affected (Fig. 2). Reductions in shoot growth due to root pruning have been reported (Arnold and Struve, 1989a, 1989b; Geisler and Ferree, 1984). Although the basis for this effect in this experiment is unknown, various factors may be involved. The removal of root tissue at planting may reduce nutrient and carbohydrate reserves as well as the root surface area available for water and nutrient uptake. Additionally, sources of hormones may have been decreased. Root tips are sources of cytokinins (Richards and Rowe, 1977; Skene, 1975), and all intact root tips were removed from root-pruned plants. Substances with gibberellin-like activity also occur in apple rootstock (Ibrahim and Dana, 1971). Changes in root and shoot growth following root pruning may be the result of alterations in source/sink relationships (Geisler and Ferree, 1984; Young and Werner, 1982).

Chilling up to $1600 \mathrm{hr}$ hastened the rate of budbreak in all species, although the magnitude of the response differed between species. Following $1600 \mathrm{CH}$, only 3 to 6 days were required for $M . \times$ robusta and $M$. ranetka to reach maximum percent budbreak (Fig. 3), whereas $M$. prunifolia required $\approx 9$ days followed by $M$. domestics, and $M$. anis, M. antonovka, and $M$. borwinka, which required between 9 and 12 days (Fig. $3)$. Some budbreak occurred in all species even in the absence of chilling (Fig. 3). Following $400 \mathrm{CH}$, there were substantial increases in the rates of budbreak and the final percent budbreak. An additional $400 \mathrm{hr}$ (to $800 \mathrm{CH}$ ) substantially increased the rates of budbreak and the final percent budbreak in $M$. $d o$ - 
Table 2. Formulas for polynomial regression equations used in Figs. 1-4. In equations: $\mathrm{CH}=$ chilling hours at $5 \mathrm{C}$, D $=$ days in greenhouse, $\mathrm{BB}=$ budbreak, NRFW $=$ new root fresh weight $(\mathrm{g})$, TLRL $=$ total large root length $(\mathrm{mm})$, and LRSA $=$ large root surface area $\left(\mathrm{mm}^{2}\right)$.

Equation $P$ 政

Equation

Figure 1

Final \% BB $=0.150+0.00038 * \mathrm{CH}-0.000000119 * \mathrm{CH}^{2}$

$\%$ buds elongating $\geqslant 3 \mathrm{~mm}=0.0823+0.000334 * \mathrm{CH}-$

0.26

0.0001

$0.0000000856 * \mathrm{CH}^{2}$

New root dry weight $(\mathrm{g})=0.000783+0.00000000127 * \mathrm{CH}^{2}$

0.41

0.0001

0.04

0.0002

New shoot fresh weight of pruned plants $(\mathrm{g})=0.0653+$

Figure 2 $0.000358 * \mathrm{CH}$

New shoot fresh weight of unpruned plants $(\mathrm{g})=0.270+$

0.0001 $0.000000575 * \mathrm{CH}^{2}$

New shoot dry weight of pruned plants $(\mathrm{g})=0.0263+$ $0.0000468 * \mathrm{CH}+0.0000000352 * \mathrm{CH}^{2}$

New shoot dry weight of unpruned plants $(\mathrm{g})=0.0712$ $0.0000156 * \mathrm{CH}+0.000000147 * \mathrm{CH}^{2}$

Total shoot length of pruned plant $(\mathrm{mm})=28.8+$

0.0001 $0.000176 * \mathrm{CH}^{2}-0.0000000617 * \mathrm{CH}^{3}$

Total shoot length of unpruned plants $(\mathrm{mm})=64.4+$ $0.000143 * \mathrm{CH}^{2}$

Number of small roots on pruned plants $=0.895-0.00379 * \mathrm{CH}+$

0.0001

0.40

0.0001

0.50

0.0001

0.45

0.0001 $0.00000346 * \mathrm{CH}^{2}$

Number of small roots on unpruned plants $=29.8+0.0000445^{*} \mathrm{CH}^{2}$

0.11

0.0001

0.14

0.0001

$\%$ BB for $M$. domestica at:

Figure 3

$0 \mathrm{CH}=-0.009+0.000622 * \mathrm{D}^{2}$

$400 \mathrm{CH}=-0.0261+0.00126 * \mathrm{D}^{2}$

$800 \mathrm{CH}=-0.0153+0.00154 * \mathrm{D}^{2}$

$1200 \mathrm{CH}=-0.0194+0.0233 * \mathrm{D}$

$1600 \mathrm{CH}=-0.00657+0.0480 * \mathrm{D}-0.00159 * \mathrm{D}^{2}$

$\%$ BB for $M$. anis at:

$0 \mathrm{CH}=-0.0103+0.000476 * \mathrm{D}^{2}$

$400 \mathrm{CH}=-0.0177+0.000813 * \mathrm{D}^{2}$

$800 \mathrm{CH}=0.0104-0.0115 * \mathrm{D}+0.00148 * \mathrm{D}^{2}$

$1200 \mathrm{CH}=-0.0159+0.00409 * \mathrm{D}^{2}-0.000151 * \mathrm{D}^{3}$

$1600 \mathrm{CH}=-0.0125+0.00792 * \mathrm{D}^{2}-0.000395 * \mathrm{D}^{3}$

0.27

0.60

0.0001

0.71

0.57

0.0001

0.56

0.0001

0.0001

0.0001

0.44

0.0001

0.34

0.0001

0.58

0.0001

0.63

0.0001

$\%$ BB for $M$. prunifolia at:

$0 \mathrm{CH}=-0.0252+0.0188 * \mathrm{D}$

0.70

0.0001

$400 \mathrm{CH}=-0.0104+0.00185 * \mathrm{D}^{2}$

$800 \mathrm{CH}=-0.0233+0.00586 * \mathrm{D}^{2}-0.000260 * \mathrm{D}^{3}$

0.57

0.70

0.0001

$1200 \mathrm{CH}=-0.0556+0.0141 * \mathrm{D}^{2}-0.000744 * \mathrm{D}^{3}$

0.72

$1600 \mathrm{CH}=0.0263+0.0708 * \mathrm{D}-0.00279 * \mathrm{D}^{2}$

0.21

0.76

0.0001

0.0001

0.0001

$\% \mathrm{BB}$ for $M$. $\times$ robusta:

$0 \mathrm{CH}=-0.00395+0.000216 * \mathrm{D}^{2}$

0.35

0.0001

$400 \mathrm{CH}=-0.00668+0.0215 * \mathrm{D}$

0.33

$800 \mathrm{CH}=-0.0537+0.0341 * \mathrm{D}$

$1200 \mathrm{CH}=-0.0239+0.0876 * \mathrm{D}-0.00325 * \mathrm{D}^{2}$

$1600 \mathrm{CH}=0.0127+0.167 * \mathrm{D}-0.0183 * \mathrm{D}^{2}+0.000638 * \mathrm{D}^{3}$

0.54

0.0001

0.0001

0.0001

0.67

0.53

0.0001

$\% \mathrm{BB}$ for $M$. antonovka:

$0 \mathrm{CH}=-0.0177+0.0162 * \mathrm{D}$

$400 \mathrm{CH}=-0.0218+0.00175 * \mathrm{D}^{2}$

0.39

0.77

0.0001

$800 \mathrm{CH}=-0.0279+0.00377 * \mathrm{D}^{2}-0.000139 * \mathrm{D}^{3}$

$1200 \mathrm{CH}=0.0148+0.00705 * \mathrm{D}^{2}-0.000347 * \mathrm{D}^{3}$

0.85

0.64

$1600 \mathrm{CH}=0.0218+0.00846 * \mathrm{D}^{2}-0.000430 * \mathrm{D}^{3}$

0.72

0.0001

0.0001

0.0001

0.0001

$\% \mathrm{BB}$ for $M$. borwinka:

$0 \mathrm{CH}=-0.00876+0.000538 * \mathrm{D}^{2}$

0.42

0.0001

$400 \mathrm{CH}=-0.0105+0.00128 * \mathrm{D}^{2}$

0.58

0.0001

$800 \mathrm{CH}=-0.0125+0.00128 * \mathrm{D}^{2}$

0.70

0.0001

$1200 \mathrm{CH}=0.00994+0.00162 * \mathrm{D}^{2}$

0.55

0.0001

$1600 \mathrm{CH}=-0.0114+0.00639 * \mathrm{D}^{2}-0.000312 * \mathrm{D}^{3}$

0.69

0.0001

$\% \mathrm{BB}$ for $M$. ranetka:

$0 \mathrm{CH}=-0.000763+0.00879 * \mathrm{D}$

0.16

0.35

0.0001

$400 \mathrm{CH}=-0.0302+0.0238 * \mathrm{D}$

0.38

0.0018

$800 \mathrm{CH}=-0.0121+0.0239 * \mathrm{D}$

$1200 \mathrm{CH}=0.0428+0.00668 * \mathrm{D}^{2}-0.000327 * \mathrm{D}^{3}$

$1600 \mathrm{CH}=0.00591+0.142 * \mathrm{D}-0.0155 * \mathrm{D}^{2}+0.000537 * \mathrm{D}^{3}$

0.38

0.50

0.0001

0.0001

0.0001

0.0001

continued 


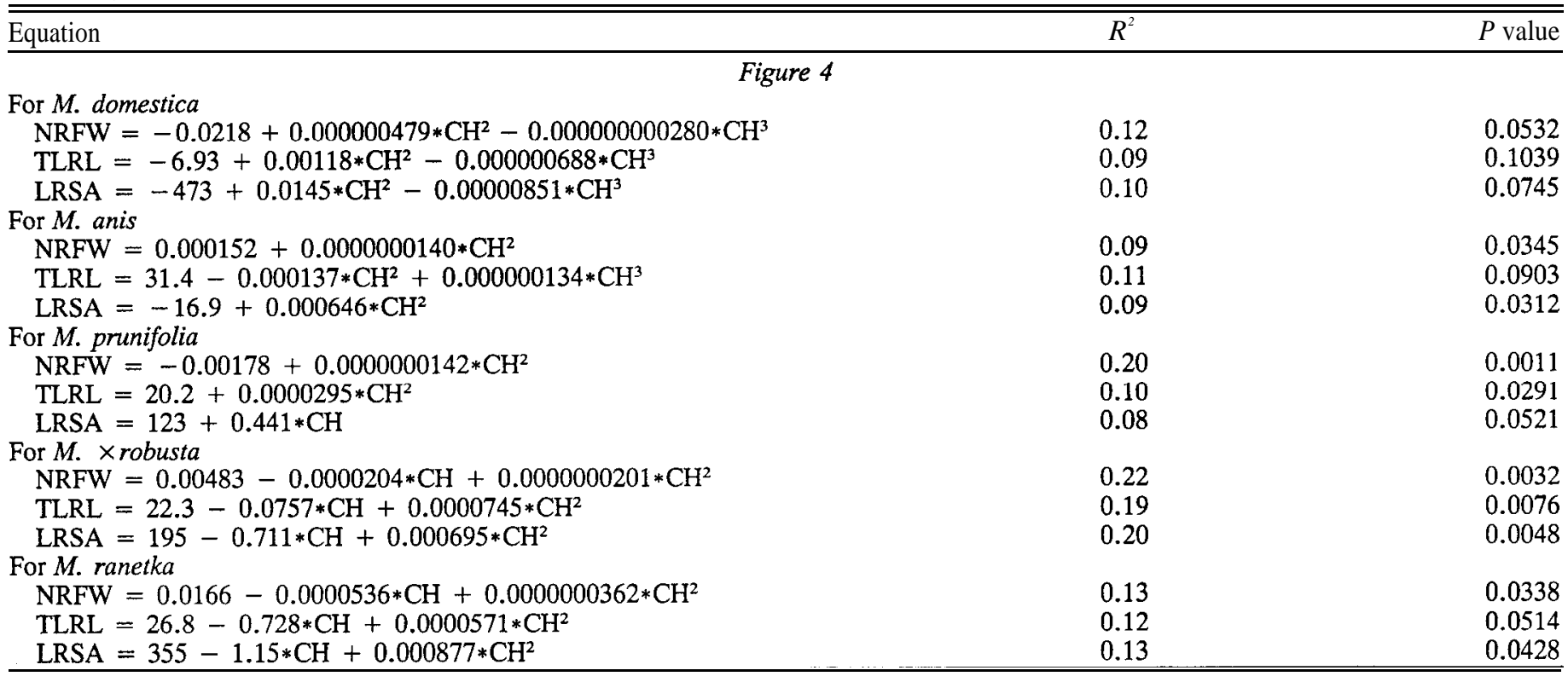

Table 3. Main effects of species on root and shoot growth of apple seedlings of seven species of Malus. ${ }^{z}$

\begin{tabular}{|c|c|c|c|c|c|c|c|}
\hline Criterion & $\begin{array}{c}\text { Malus } \\
\text { domestics }\end{array}$ & $\begin{array}{l}\text { Malus } \\
\text { anis }\end{array}$ & $\begin{array}{c}\text { Malus } \\
\text { prunifolia }\end{array}$ & $\begin{array}{l}\text { Malus } \\
\times \text { robusta }\end{array}$ & $\begin{array}{c}\text { Malus } \\
\text { antonovka }\end{array}$ & $\begin{array}{c}\text { Malus } \\
\text { borwinka }\end{array}$ & $\begin{array}{c}\text { Malus } \\
\text { ranetka }\end{array}$ \\
\hline Budbreak (\%) & $28 \mathrm{a}$ & $26 \mathrm{a}$ & $41 \mathrm{~b}$ & $39 \mathrm{~b}$ & $37 \mathrm{~b}$ & $28 \mathrm{a}$ & $39 \mathrm{~b}$ \\
\hline $\begin{array}{l}\text { S h o o t s } \\
\geq 3 \mathrm{~mm}(\%)\end{array}$ & $23 \mathrm{ab}$ & $21 \mathrm{a}$ & $33 \mathrm{c}$ & $30 \mathrm{c}$ & $31 \mathrm{c}$ & $22 \mathrm{ab}$ & $28 \mathrm{bc}$ \\
\hline $\begin{array}{l}\text { New root } \\
\text { to shoot } \\
\text { dry wt }\left(\mathrm{g} \cdot \mathrm{g}^{-1}\right)\end{array}$ & $0.005 \mathrm{a}$ & $0.002 \mathrm{a}$ & $0.002 \mathrm{~b}$ & $0.001 \mathrm{~b}$ & $0.001 \mathrm{~b}$ & $0.002 \mathrm{~b}$ & $0.001 \mathrm{~b}$ \\
\hline
\end{tabular}

${ }^{2}$ Within criteria means followed by the same letter are not significantly different at $P \geq .01$. Values are means of 25 observations.

mestica and $M . \times$ robusta, whereas, for $M$. prunifolia and $M$. antonovka, the rates of budbreak increased, but the final percent budbreak did not. For $M$. anis, $M$. borwinka, and $M$. ranetka, little change in the rates of budbreak or the final percent budbreak were evident when chilling was increased from 400 to $800 \mathrm{hr}$. An increase from 800 to 1200 and 1200 to $1600 \mathrm{CH}$ resulted in a substantial increase in the rate of budbreak for all species. For some species, this increase represented shoot growth enhancement due to over-chilling (beyond the $\mathrm{CH}$ required for maximum final percent budbreak). Changes in rate or extent of budbreak following 800 and $1200 \mathrm{CH}$ and/or between 1200 and $1600 \mathrm{CH}$ depended on whether the species' chilling requirement had been satisfied. Enhancement of budbreak by prolonged chilling has been reported for $M$. domestics, Prunus avium L., Prunus persica (L.) Batsch, and Pyrus communis $\times$ Pyrus pyrifolia (Burm) Nakai (Couvillon and Erez, 1985).

Chilling hour requirement data (estimated by the lowest $5 \mathrm{C}$ $\mathrm{CH}$ curve for budbreak that plateaued) indicated that $M$. prunifolia had the lowest $\mathrm{CH}$ requirement (between 800 and 1200 $\mathrm{CH}$, but closer to $800 \mathrm{CH}$ ), as evidenced by a reduced rate of budbreak beginning at $800 \mathrm{CH}$ (Fig. 3, Table 2). We cannot account for the greater budbreak for M. prunifolia at $1200 \mathrm{CH}$ than at $1600 \mathrm{CH}$. Malus antonovka, M. $\times$ robusta, and $M$. ranetka also had $\mathrm{CH}$ requirements between 800 and $1200 \mathrm{CH}$, but higher than that of M. prunifolia (Fig. 3). Malus domestica,
$M$. anis, and $M$. borwinka had the highest $\mathrm{CH}$ requirements, between 1200 and $1600 \mathrm{CH}$ (Fig. 3). Based on the lowest $\mathrm{CH}$ curve to plateau for each species (Fig. 3), the growing degree hour (GDH) requirements for $90 \%$ of maximum observed budbreak of all species, except for $M$. x robusta, were calculated to be between 3402 and $4536 \mathrm{GDH}$. Malus $\times$ robusta had a lower GDH requirement, between 2268 and $3402 \mathrm{GDH}$, than the other six species. $\mathrm{CH}$ requirements agreed with those reported for some clonal $M$. domestics rootstock, but GDH requirements were somewhat lower than those reported for $M$. domestics and M. antonovka clones (Young and Werner, 1985a).

Root growth responses. Since nearly all small roots regenerated from lateral roots that existed at planting, root pruning greatly reduced the number of small roots regenerated in all species (Table 4) and at all chilling treatments (Fig. 2). In this respect, species tended to fall into three groups: $M$. prunifolia and $M . \times$ robusta producing many small roots; $M$. antonovka and $M$. ranetka moderate numbers; and $M$. domestics, $M$. anis, and $M$. borwinka the fewest (Table 4). Across species, the number of small roots regenerated by unpruned plants remained low for the first few hundred chilling hours and then began to increase, whereas the number on root-pruned plants remained near zero through $1600 \mathrm{CH}$ (Fig. 2). Root pruning affected both the timing and magnitude of small root regeneration. Root pruning drastically reduced the number of small roots regenerated, par- 
Table 4. Interactions between root pruning and species on root and shoot growth of seven species of Malus averaged across chilling treatments. ${ }^{2}$

\begin{tabular}{|c|c|c|c|c|c|c|c|c|c|}
\hline \multirow[b]{3}{*}{ Species } & \multirow[b]{3}{*}{$\begin{array}{c}\text { Root } \\
\text { pruned }\end{array}$} & & & \multicolumn{3}{|c|}{ New large root } & \multirow{2}{*}{\multicolumn{3}{|c|}{ New shoot }} \\
\hline & & \multicolumn{2}{|c|}{ No. new roots } & \multirow{2}{*}{$\begin{array}{c}\text { Surface } \\
\text { area } \\
\left(\mathrm{mm}^{2}\right)\end{array}$} & \multirow[b]{2}{*}{$\begin{array}{c}\text { Length } \\
(\mathrm{mm})\end{array}$} & \multirow[b]{2}{*}{$\begin{array}{l}\text { Fresh } \\
\text { wt (g) }\end{array}$} & & & \\
\hline & & $<0.6 \mathrm{~mm}$ & $\geq 0.6 \mathrm{~mm}$ & & & & $\begin{array}{l}\text { Length } \\
(\mathrm{mm})\end{array}$ & $\begin{array}{l}\text { Fresh } \\
\text { wt (g) }\end{array}$ & $\begin{array}{c}\text { Dry } \\
\text { wt }(\mathrm{g})\end{array}$ \\
\hline Malus & Yes & $2 a$ & $20 \mathrm{a}$ & $4331 \mathrm{a}$ & $409 \mathrm{a}$ & $0.14 \mathrm{a}$ & $148 \mathrm{a}$ & $0.44 \mathrm{a}$ & $0.11 \mathrm{a}$ \\
\hline domestics & $\mathrm{No}$ & $25 \mathrm{a}$ & $5 \mathrm{~b}$ & $811 \mathrm{~b}$ & $83 \mathrm{~b}$ & $0.02 \mathrm{~b}$ & $165 \mathrm{a}$ & $0.56 \mathrm{a}$ & $0.14 \mathrm{a}$ \\
\hline \multirow[t]{2}{*}{ M. anis } & Yes & $1 \mathrm{a}$ & $5 \mathrm{a}$ & $802 \mathrm{a}$ & $98 \mathrm{a}$ & $0.02 \mathrm{a}$ & $100 \mathrm{a}$ & $0.32 \mathrm{a}$ & $0.08 \mathrm{a}$ \\
\hline & No & $20 \mathrm{a}$ & $2 a$ & $404 \mathrm{a}$ & $46 \mathrm{a}$ & $0.01 \mathrm{a}$ & $121 \mathrm{a}$ & $0.44 \mathrm{a}$ & $0.11 \mathrm{a}$ \\
\hline \multirow[t]{2}{*}{ M. prunifolia } & Yes & $1 \mathrm{a}$ & $1 \mathrm{a}$ & $128 \mathrm{a}$ & $10 \mathrm{a}$ & $0.01 \mathrm{a}$ & $125 \mathrm{a}$ & $0.41 \mathrm{a}$ & $0.12 \mathrm{a}$ \\
\hline & No & $195 \mathrm{~b}$ & $5 a$ & $824 \mathrm{a}$ & $87 \mathrm{a}$ & $0.02 \mathrm{a}$ & $247 \mathrm{~b}$ & $1.47 \mathrm{~b}$ & $0.35 \mathrm{~b}$ \\
\hline \multirow[t]{2}{*}{ M. $\times$ robusta } & Yes & $1 \mathrm{a}$ & $1 \mathrm{a}$ & $116 \mathrm{a}$ & $10 \mathrm{a}$ & $0.00 \mathrm{a}$ & $143 \mathrm{a}$ & $0.31 \mathrm{a}$ & $0.10 \mathrm{a}$ \\
\hline & No & $104 \mathrm{~b}$ & $3 a$ & $471 \mathrm{a}$ & $56 \mathrm{a}$ & $0.01 \mathrm{a}$ & $279 \mathrm{~b}$ & $0.97 \mathrm{~b}$ & $0.21 \mathrm{~b}$ \\
\hline \multirow[t]{2}{*}{ M. antonovka } & Yes & $0 \mathrm{a}$ & $1 \mathrm{a}$ & 89 a & $10 \mathrm{a}$ & $0.00 \mathrm{a}$ & $100 \mathrm{a}$ & $0.34 \mathrm{a}$ & $0.10 \mathrm{a}$ \\
\hline & No & $76 \mathrm{~b}$ & $3 a$ & 338 a & $39 a$ & $0.01 \mathrm{a}$ & $226 \mathrm{~b}$ & $1.07 \mathrm{~b}$ & $0.26 \mathrm{~b}$ \\
\hline \multirow[t]{2}{*}{ M. borwinka } & Yes & $3 a$ & $5 \mathrm{a}$ & $1342 \mathrm{a}$ & $117 \mathrm{a}$ & $0.03 \mathrm{a}$ & $96 \mathrm{a}$ & $0.32 \mathrm{a}$ & $0.08 \mathrm{a}$ \\
\hline & No & $16 \mathrm{a}$ & $2 \mathrm{a}$ & $305 \mathrm{a}$ & $32 \mathrm{a}$ & $0.01 \mathrm{a}$ & $157 \mathrm{a}$ & $0.53 \mathrm{a}$ & $0.13 \mathrm{a}$ \\
\hline \multirow[t]{2}{*}{ M. ranetka } & Yes & $0 \mathrm{a}$ & $1 \mathrm{a}$ & 359 a & $23 \mathrm{a}$ & $0.01 \mathrm{a}$ & $121 \mathrm{a}$ & $0.32 \mathrm{a}$ & $0.09 \mathrm{a}$ \\
\hline & No & $73 \mathrm{~b}$ & $2 \mathrm{a}$ & $187 \mathrm{a}$ & $24 \mathrm{a}$ & $0.00 \mathrm{a}$ & $217 \mathrm{~b}$ & $0.72 \mathrm{~b}$ & $0.20 \mathrm{~b}$ \\
\hline
\end{tabular}

${ }^{2}$ Within species and criteria means followed by the same letter are not significantly different at $P \leq 0.01$. Values are means of 35 observations.

${ }^{y}<0.6 \mathrm{~mm}=$ small and $\geq 0.6 \mathrm{~mm}=$ large roots.
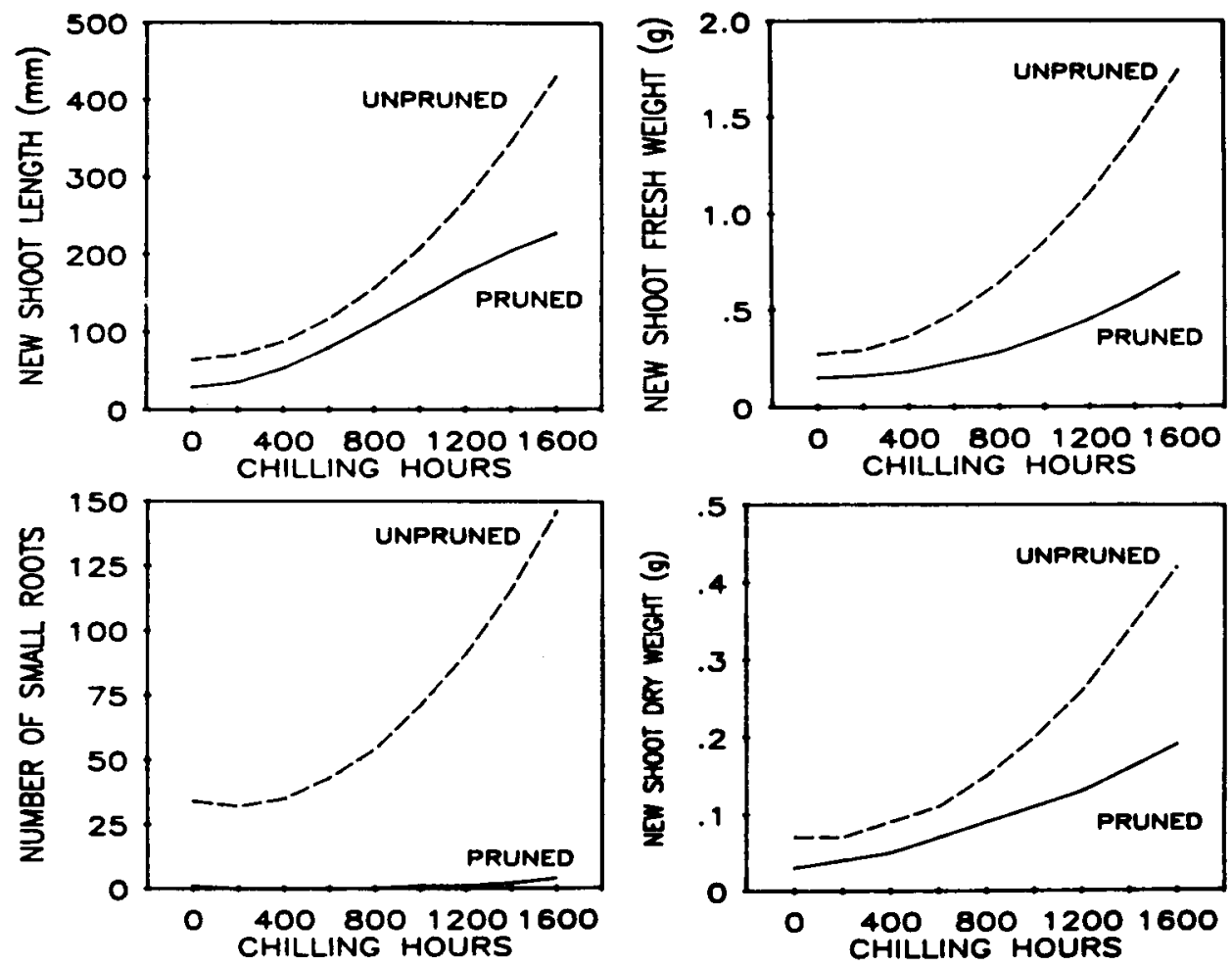

Fig. 2. Interactions between root pruning and chilling hours at $5 \mathrm{C}$ on new shoot fresh weight, new shoot dry weight, total new shoot length, and the number of small roots of seedlings (across seven species) after 15 days in a greenhouse. Regression equations are presented in Table 2.

titularly at higher chilling levels (Fig. 2). Increases in the number of small roots regenerated (Fig. 2) occurred earlier in unpruned plants (400 to $800 \mathrm{CH}$ ) then in root-pruned plants (800 to 1200 CH). This result agrees with those of DeWald and Feret (1987) on Pinus taeda L.- when shoots were dormant or quiescent, new root growth consisted primarily of elongation of existing roots, rather than initiation of new roots.

Species differences in responses of large roots to chilling and root pruning were also apparent. Across chilling treatments, the number of large roots regenerated was unaffected by root prun- ing for all species, except $M$. domestics, in which root pruning stimulated root production (Table 4). This same pattern was reflected in the root length, root surface area, and new root fresh weights (Table 4). Species differences in the number of roots regenerated were also reported by Gilman and Yeager (1988) in studies on autumn root regeneration of some deciduous hardwood species, although they did not distinguish between root sizes.

Across species, new root dry weights began to increase after $\approx 400 \mathrm{CH}$ and continued to increase through $1600 \mathrm{CH}$ (Fig. 1). 

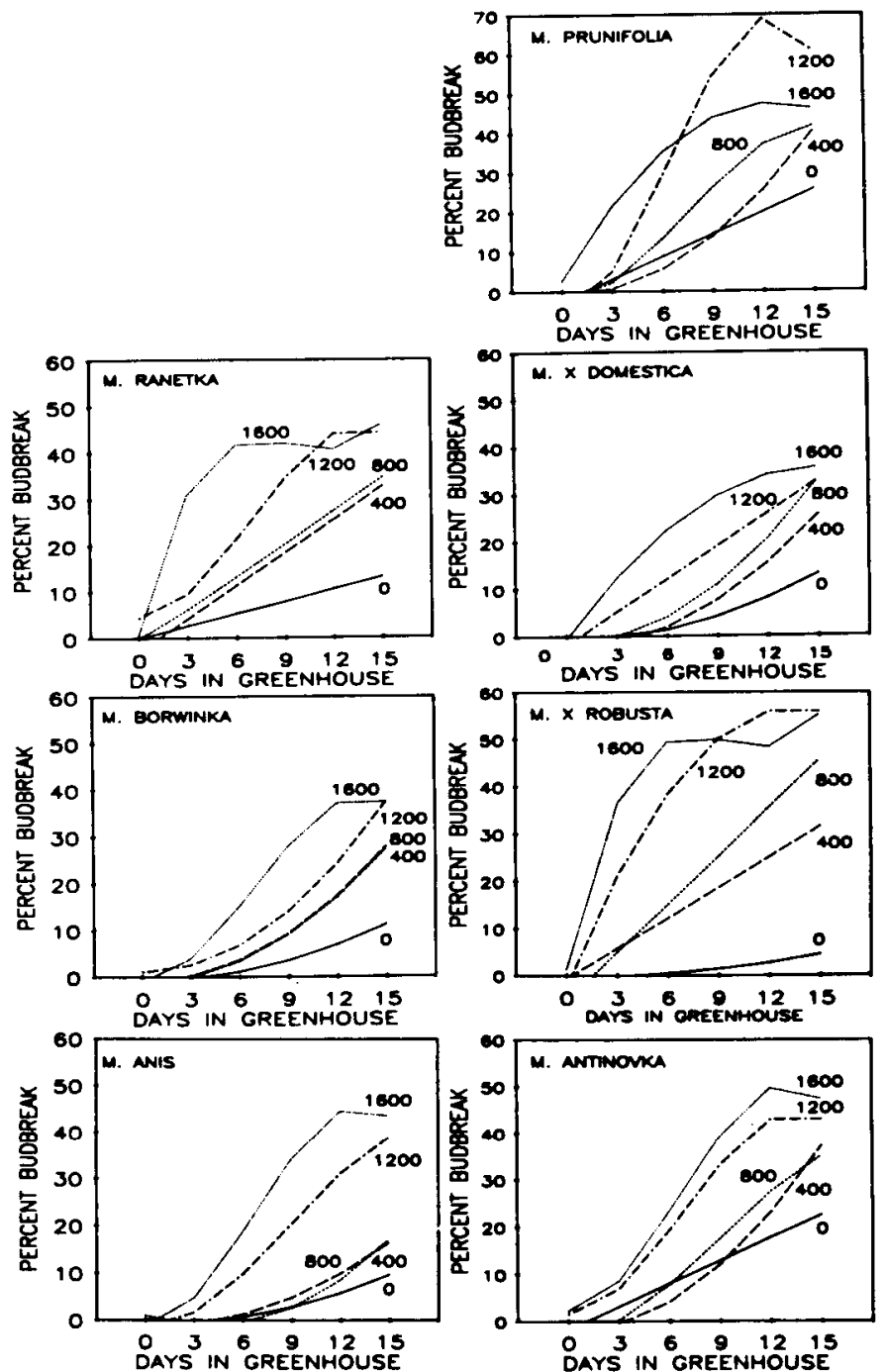

Fig. 3. Effects of chilling hours $(\mathrm{CH})$ at $5 \mathrm{C}$ on budbreak of seven species of Malus. Regression equations are presented in Table 2.

Also, the ratio of dry weights of regenerated large roots to that of new shoots was greater for $M$. domestics than for other species (Table 3). While these effects on the large root dry weight were significant (Table 1), the weights fell near the precision error of the balance used $( \pm 5 \mathrm{mg})$, and thus may not be as reliable as other measures of large root regeneration (large root fresh weight, total length, and surface area).

Across root pruning treatments, two patterns of responses of large roots to chilling were apparent, and all three measures of root growth followed the same pattern (Fig. 4, Table 2). For $M$. domestics, regeneration of large roots began to increase before $400 \mathrm{CH}$, rose through $1200 \mathrm{CH}$, then decreased to 1600 CH. In $M$. anis, M. prunifolia, $M$. × robusta, and $M$. ranetka, regeneration remained at a low level or decreased slightly through $800 \mathrm{CH}$ and then increased through $1600 \mathrm{CH}$. Regression coefficients (for the three characteristics vs. $\mathrm{CH}$ ) were not significant in $M$. antonovka and $M$. borwinka.

Increases in-root regeneration potential during winter (outdoors) or during artificial chilling have been reported in $M$. domestics (Young and Werner, 1984b, 1985b, 1986), Quercus rubra L. (Farmer, 1975), Fraxinus americana L. (Webb, 1976), A. saccharum (Webb, 1977), Pinus ponderosa (Stone and Nor-
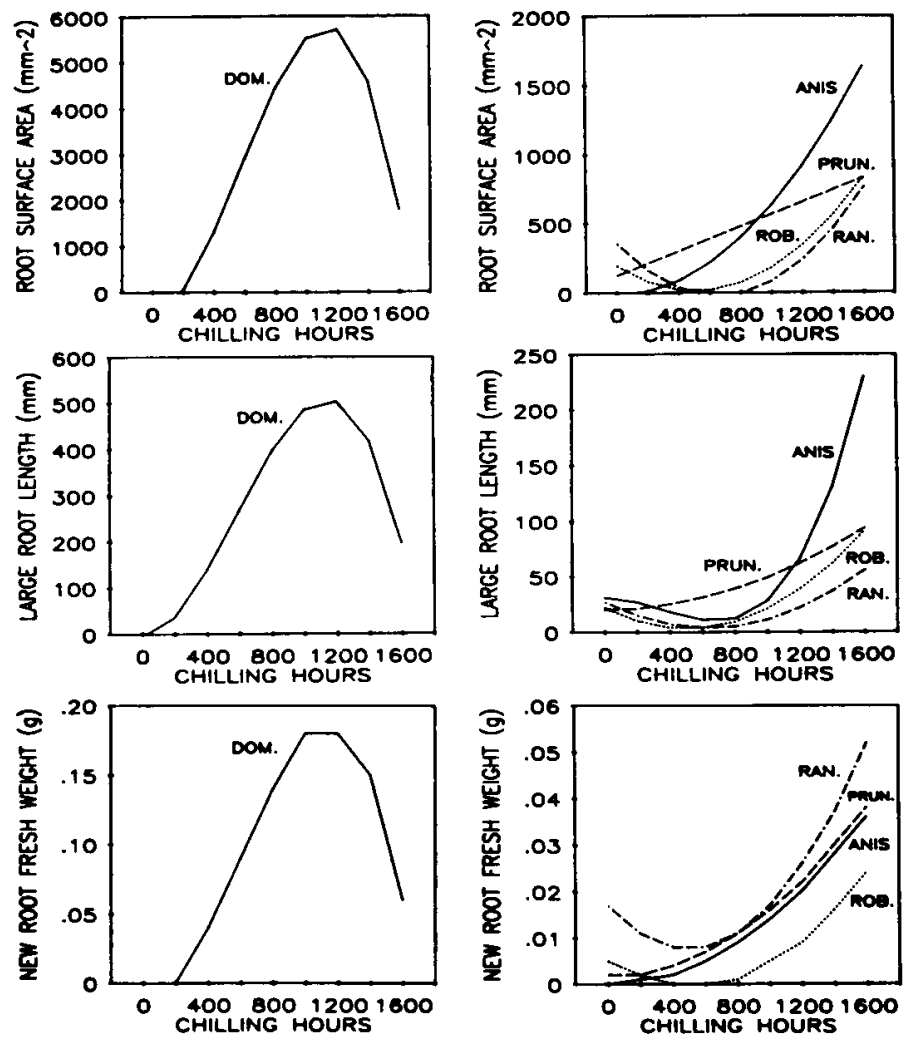

Fig.4. Interactions between species and chilling hours at 5C on new root fresh weight, total large root length, and large root surface area of seven species of Malus. Abbreviations on graphs are: DOM. = Malus domestics, ANIS = Malus anis, PRUN. = Malus prunifolia, ROB. = Malus $\times$ robusta, RAN. = Malus ranetka . Regression equations are presented in Table 2.

berg, 1979), P. taeda (DeWald et al., 1985), and Taxus cuspidata (Lathrop and Mecklenburg, 1971). Differences in root regeneration in response to chilling between $M$. domestia rootstock (Young and Werner, 1984) and half-sib families of $P$. taeda (DeWald et al., 1985) have also been shown. The present study demonstrates quantitative differences between species of Malus in root growth responses to chilling. Because differences in root regeneration potential between half-sib families of $P$. taeda (DeWald et al., 1985) and Pinus radiata Don (Nambiar et al., 1982) are highly heritable, such differences may be exploitable traits for apple rootstock breeding.

\section{Literature Cited}

Arnold, M.A. and D.K. Struve. 1989. Green ash establishment following transplant. J. Amer. Sot. Hort. Sci. 114:591-595.

Arnold, M.A. and D.K. Struve. 1989. Growing green ash and red oak in $\mathrm{CuCO}_{3}$-treated containers increases root regeneration and shoot growth following transplant. J. Amer. Soc. Hort. Sci. 114:402-406.

Couvillon, G.A. and A. Erez. 1985. Influence of prolonged exposure to chilling temperatures on bud break and heat requirement for bloom of several fruit species. J. Amer. Soc. Hort. Sci. 110:4750 .

DeWald, L. E., P.P. Feret, and R.E. Kreh. 1985. Genetic variation in loblolly pine root growth potential. Proc. 18th South. For. Tree Imp. Conf., Long Beach, Calif. 21-24 May.

DeWald, L.E. and P.P. Feret. 1987. Changes in loblolly pine root growth potential from September to April. Can. J. For. Res. 17:635643. 
Farmer, R. E., Jr. 1975. Dormancy and root regeneration of northern red oak. Can. J. For. Res. 5:176-185.

Geisler, D. and D.C. Ferree. 1984. Response of plants to root pruning. Hort. Rev. 6:155-188.

Gilman, E.D. and T.H. Yeager. 1988. Root initiation in root-pruned hardwoods. HortScience 23:775.

Ibrahim, I.M. and M.N. Dana. 1971. Gibberellin-like activity in apple rootstock. HortScience 6:541-542.

Lathrop, J.K. and R.A. Mecklenburg. 1971. Root regeneration and root dormancy in Taxus spp. J. Amer. Soc. Hort. Sci. 96:11 1-1 14.

Nambiar, E. K. S., P.P. Cotterill, and G.D. Bowen. 1982. Genetic differences in the root regeneration of radiata pine. J. Expt. Bet. 33:170-177.

Richards, D. and R.N. Rowe. 1977. Root-shoot interactions in peach: The function of the root. Ann. Bet. 41:1211-1216.

SAS Institute. 1985. SAS user's guide: Statistics, Version 5 ed. SAS Institute, Inc., Cary, N.C.

Skene, K.G.M. 1975. Cytokinin production by roots as a factor in the control of plant growth, p. 365-396. In: J.G. Torrey and D.T. Clarkson (eds.). The development and function of roots. Academic, New York.

Stone, E.C. and E.A. Norberg. 1979. The effect of lifting dates and cold storage on the root growth capacity of bare-root coniferous seedlings. School on Forest Regeneration, Sacramento, Calif. 19 July 1979. p. 1-30.
Webb, D.P. 1976. Effects of cold storage duration on bud dormancy and root regeneration of white ash (Fraxinus americana L.) seedlings. HortScience 11:155-157.

Webb, D.P. 1977. Root regeneration and bud dormancy of sugar maple, silver maple, and white ash seedlings: Effects of chilling. For. Sci. 23:474-483.

Young, E. and D.J. Werner. 1982. Early season root and shoot growth of 'Golden Delicious' apple on four rootstock as affected by pruning at planting. J. Amer. Soc. Hort. Sci. 107:822-826.

Young, E. and D.J. Werner. 1984a. A nondestructive method for measuring shoot and root fresh weights. HortScience 19:554-555.

Young, E. and D.J. Werner. 1984b. Effects of rootstock and scion chilling during rest on resumption of growth in apple and peach. J. Amer. Soc. Hort. Sci. 109:548-551.

Young, E. and D.J. Werner. 1985a. Chill unit and growing degree hour requirements for vegetative bud break in six apple rootstock. J. Amer. Soc. Hort. Sci. 110:411-413.

Young, E. and D.J. Werner. 1985b. Effects of shoot, root, and shank chilling during rest in apple and peach on growth resumption and carbohydrates. J. Amer. Soc. Hort. Sci. 110:769-774.

Young, E. and D.J. Werner. 1986. 6-BA applied after shoot and/or root chilling and its effect on growth resumption in apple and peach. HortScience 21:280-281. 